\title{
Cato the Elder, Livy, and Xenophon's Anabasis
}

Tim Rood

St Hugh's College, Oxford

timothy.rood@st-hughs.ox.ac.uk

\begin{abstract}
This article argues firstly that Cato the Elder's account of a daring plan involving the tribune Caedicius in the First Punic War is modelled on a scene in Xenophon's Anabasis. It then argues that Livy's account of a heroic escape in the First Samnite War orchestrated by P. Decius Mus is modelled not just on the First Punic War episode described by Cato, as scholars have suggested, but on the same passage of Xenophon; it also proposes that Livy's use of Xenophon may be mediated through Cato. The article then sets out other evidence for the use of Xenophon in Roman historiography and explores the implications of the proposed intertextuality for Roman self-positioning and for ideas of leadership and military hierarchy. The article as a whole suggests that the influence of Xenophon on Latin historiography is greater than has often been conceived.
\end{abstract}

\section{Keywords}

Cato the Elder; Livy; Xenophon; Greek and Roman historiography; intertextuality.

One of the most famous fragments of Cato the Elder's Origines is the story of a military tribune who, while serving in Sicily in the First Punic War, explains to his superior officer (the consul Atilius) that there is a chance for the army to escape from the position of 
entrapment in which it has found itself (FRHist 5 F76 = Gell. 3.7) ${ }^{1}$ this episode has in turn been seen as the model for Livy's account of a heroic escape in the First Samnite War orchestrated by P. Decius Mus (7.34-36). The first two parts of this article will make a new proposal about a model both for Cato's First Punic War episode and for Livy's Decius narrative - an exciting scene from the third book of Xenophon's Anabasis. The third part will support this argument by reviewing the evidence for knowledge of Xenophon in Roman historians in the first two centuries BC. The final part of the article will then explore the implications the Xenophontic intertextuality has for the self-positioning of the Roman historians and for the presentation of military leadership and hierarchy.

\section{Cato's Caedicius}

Most of the story of the tribune survives in a paraphrase and short extract offered by Aulus Gellius, who introduces it as pulcrum, dii boni, facinus Graecarumque facundiarum magniloquentia condignum ('a glorious deed, by the Gods! and well worthy of the noble strains of Greek eloquence'). While it is likely enough that the basic narrative structure preserved by Gellius reflects Cato's original, one point of uncertainty is whether Cato actually named the tribune: Gellius introduces his paraphrase as a story about a tribune called Caedicius, but no name is given in either his paraphrase or the extract he gives - an omission that is thought to chime with ancient testimonies that Cato omitted personal names. ${ }^{2}$ Some

1 The episode appears in some other historians with various differences; the fullest discussions are Calboli 1996; Cornell, FRHist 3.121-124.

${ }^{2} \mathrm{~T} 1$ = Nepos, Cato 3.4: horum bellorum duces non nominauit, sed sine nominibus res notauit ('the commanders in these wars he did not name, but registered the events without the 
scholars, however, have accepted that Cato is the source for the name Gellius gives (especially as other accounts offer different names and Gellius himself names a source (Claudius Quadrigarius) for one of these variants (Laberius)), assuming that Cato must have provided names for office-holders at the beginning of each campaign section. ${ }^{3}$ As we shall see, the question as to whether Cato named Caedicius is of some importance for how we interpret the use of Xenophon that I will be proposing, but it does not bear on the case for the intertextuality itself. To support that case, it will be helpful to quote the beginning of Gellius' paraphrase in full:

Imperator Poenus in terra Sicilia bello Carthaginiensi primo obuiam Romano exercitu progreditur, colles locosque idoneos prior occupat. Milites Romani, uti res nata est, in locum insinuant fraudi et perniciei obnoxium. Tribunus ad consulem uenit, ostendit

names'); T20 = Pliny, NH 8.11: cum imperatorum nomina annalibus detraxerit ('although he removed the names of generals from his annals').

${ }^{3}$ Most scholars express some uncertainty on this issue, but Albrecht 1989, 28 n. 110; Calboli 1996, 5-9; Holford-Strevens 2003, 249 think it more likely that Cato named the tribune, while Goldberg 2005, 28 n. 25; Dillery 2009, 102; Gotter 2009, 111-112; Briscoe 2010: 157; Popov-Reynolds 2010, 179; Samotta 2012, 355, 358 think it more likely that he did not. The matter is left open by Astin 1978, 232 n. 59; Chassignet 1986, 87 n. 1; Oakley 1997-2005, 2.333; Cornell, FRHist 1.215-16, 3.121-2. Cato's practice could have been a more rigid version of Livy's common technique of using consul after an initial introduction (e.g., in describing a campaign by Cato himself, Livy uses forms of consul at 34.11.1, 11.3, 12.1, 13.1, 14.3, 14.6, 14.7, 14.8, 15.1, but then 'Cato' at 34.15.3); Cato could, however, have named consuls each year but not military tribunes, and Frontinus, Strat. 1.5.15, reports that nonnulli gave the name 'Caedicius'. 
exitium de loci importunitate et hostium circumstantia maturum. 'Censeo,' inquit 'si rem seruare uis, faciundum, ut quadringentos aliquos milites ad uerrucam illam' - sic enim Cato locum editum asperumque appellat - 'ire iubeas, eamque uti occupent, imperes horterisque; hostes profecto ubi id uiderint, fortissimus quisque et promptissimus ad occursandum pugnandumque in eos praeuertentur unoque illo negotio sese alligabunt, atque illi omnes quadringenti procul dubio obtruncabuntur. Tunc interea occupatis in ea caede hostibus tempus exercitus ex hoc loco educendi habebis. Alia nisi haec salutis uia nulla est.' Consul tribuno respondit consilium quidem istud aeque prouidens sibi uiderier; 'sed istos' inquit 'milites quadringentos ad eum locum in hostium cuneos quisnam erit, qui ducat?' 'Si alium' inquit tribunus 'neminem reperis, me licet ad hoc periculum utare; ego hanc tibi et reipublicae animam do.' Consul tribuno gratias laudesque agit. Tribunus et quadringenti ad moriendum proficiscuntur. Hostes eorum audaciam demirantur; quorsum ire pergant, in exspectando sunt. Sed ubi apparuit ad eam uerrucam occupandam iter intendere, mittit adversum illos imperator Carthaginiensis peditatum equitatumque, quos in exercitu uiros habuit strenuissimos. (FRHist 5 F76 = Gell. 3.7)

In the first Punic war the Carthaginian general in Sicily advanced to meet the Roman army and was first to take possession of the hills and strategic points. As the result of this, the Roman soldiers made their way into a place exposed to surprise and extreme danger. The tribune went to the consul and pointed out that destruction was imminent from their unfavourable position and from the fact that the enemy had surrounded them. 'My advice is,' said he, 'if you want to save the day, that you order some four hundred soldiers to advance to yonder wart' - for that is Cato's term for a high and rough bit of ground - 'and command and conjure them to hold it. When the enemy 
see that, undoubtedly all their bravest and most active men will be intent upon attacking and fighting with them; they will devote themselves to that one task, and beyond a doubt all those four hundred will be slaughtered. Then in the meantime, while the enemy is engaged in killing them, you will have time to get the army out of this position. There is no other way of safety but this.' The consul replied to the tribune that the plan seemed to him equally wise; 'but who, pray,' said he, 'will there be to lead those four hundred men of yours to that place in the midst of the enemy's troops?' 'If you find no one else,' answered the tribune, 'you may use me for that dangerous enterprise. I offer this life of mine to you and to my country.' The consul thanked and commended the tribune. The tribune and his four hundred marched forth to death. The enemy marvelled at their boldness; they were on tiptoe of expectation to see where they would go. But when it appeared that they were on their way to occupy that hill, the Carthaginian commander sent against them the strongest men in his army, horse and foot. ${ }^{4}$

All the troops on the hill are then killed, except for the tribune himself, who is later discovered among the corpses, wounded but still alive, by his fellow Romans, who had withdrawn to high ground in the meantime.

Cato concluded the episode by introducing a comparison with the Spartan king Leonidas that leads on to reflections on the vicissitudes of fame. Here Gellius does provide Cato's actual words:

Leonides Laco, qui simile apud Thermopylas fecit, propter eius uirtutes omnis Graecia gloriam atque gratiam praecipuam claritudinis inclitissimae decorauere

\footnotetext{
${ }^{4}$ Translations are adapted from the relevant Loeb editions or from FRHist.
} 
monumentis: signis, statuis, elogiis, historiis aliisque rebus gratissimum id eius factum habuere; at tribuno militum parua laus pro factis relicta, qui idem fecerat atque rem seruauerat.

The Laconian Leonidas, who performed a like exploit at Thermopylae, because of his valour won unexampled glory and gratitude from all Greece, and was honoured with memorials of the highest distinction; they showed their appreciation of that deed of his by pictures, statues and honorary inscriptions, in their histories, and in other ways; but the tribune of the soldiers, who had done the same thing and saved the state, gained small glory for his deeds.

The use of the Ionic spelling Leonides suggests that Cato was directly engaging with Herodotus $;{ }^{5}$ it has also been argued that Gellius' paraphrase includes some direct Herodotean echoes that go back to Cato himself. ${ }^{6}$ While these Herodotean linguistic resonances are important, it was Xenophon who provided the material from which Cato developed the Caedicius episode.

The scene in the Anabasis on which Cato's episode is modelled occurs in the early stages of the Greek retreat. The army has been pressed by the Persians from the rear. But after a few days the Persians suddenly reappear, advancing by night and seizing the spur

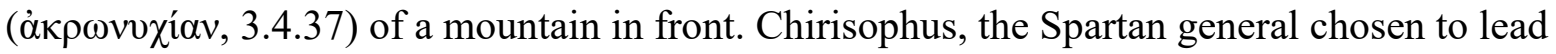
the vanguard, summons Xenophon, who is one of two generals in the rear, telling him to bring the peltasts with him. Xenophon comes by himself without the peltasts, since the

\footnotetext{
${ }^{5}$ Courtney 1999, 78.

${ }^{6}$ Krebs 2006; Cohee 2007, 369.
} 
Persians are now pressing the Greek army from the rear too. Chirisophus then asks about the problem in front:

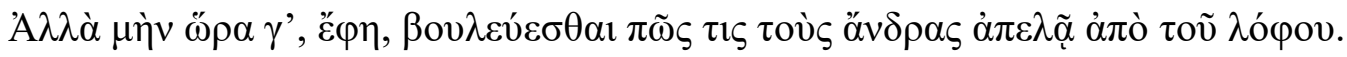

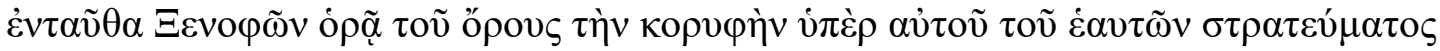

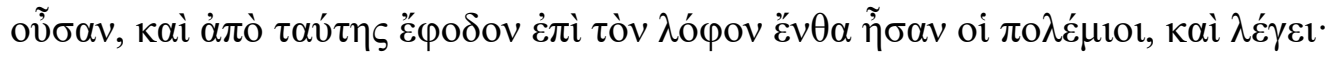

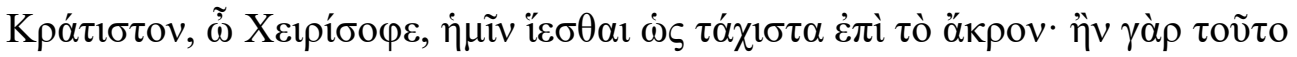

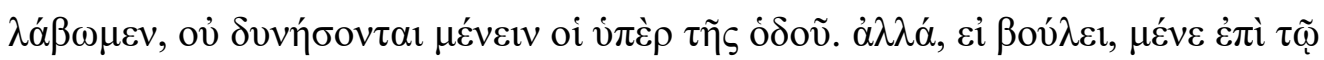

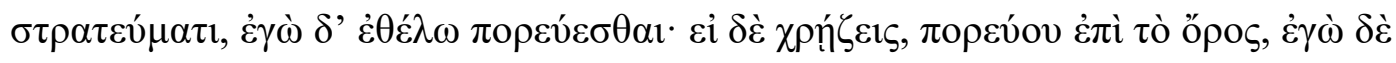

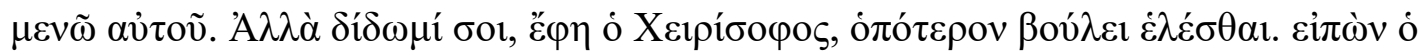

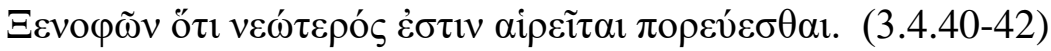

'Well, at any rate,' said Cheirisophus, 'it is high time to be thinking how we are to drive these fellows from the height.' Then Xenophon observed that the summit of the mountain was close above their own army and that from this summit there was a way of approach to the hill where the enemy were; and he said, 'Our best plan, Cheirisophus, is to drive with all speed for the mountain top; for if we once get possession of that, those men above our road will not be able to hold their position. If you choose, then, stay in command of the army, and I am willing to go; or, if you prefer, you make for the mountain top, and I will stay here.' 'Well,' said Cheirisophus, 'I leave it to you to choose which part you wish.' Then Xenophon, remarking that he was younger, elected to go.

The select force's race up the hill is then eagerly observed by both sides: 


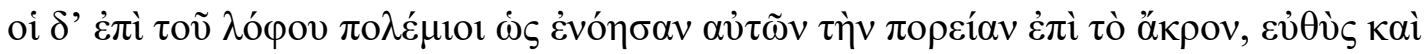

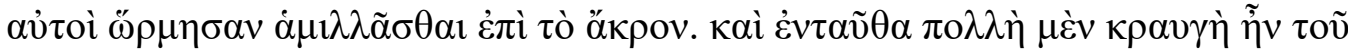

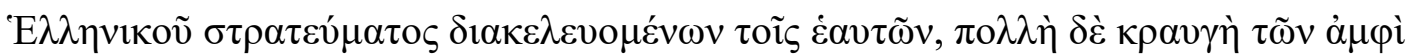

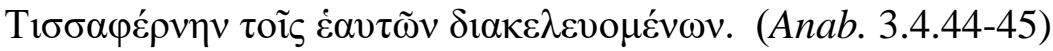

But no sooner had the enemy upon the hill observed their dash for the summit of the mountain than they also set off, to race with the Greeks for this summit. Then there was a deal of shouting from the Greek army as they urged on their friends, and just as much shouting from Tissaphernes' troops to urge on their men.

The Greeks win the race, and the Persians at once abandon their plan to block the Greeks. This passage has six striking points of similarity with Cato's account of Caedicius: 1. An army's path is blocked ahead by an enemy that has occupied higher ground. 2. A junior officer $^{7}$ observes some high ground that the enemy has not occupied. 3. A senior officer asks

${ }^{7}$ While the difference of status is clear in Cato, in the Anabasis there is nominally no distinction among the seven generals in command following the arrest of five of the original generals. Chirisophus is, however, presented as in some sense primus inter pares: he is sole leader of the vanguard, a position proposed at Xenophon's suggestion, on the grounds that he is a Spartan (3.2.37); it is for the same reason that he briefly serves as single leader later in the march along the Black Sea coast (6.1.32). Xenophon, by contrast, is in the rear as one of the two youngest generals (3.2.37), and in our passage he mentions the fact that he is younger than Chirisophus when choosing to lead the sortie up the hill (3.4.42, cited above). Also in relation to our passage, Cawkwell 2004, 63, suggests that 'the truth perhaps slipped out ... when Xenophon said that Chirisophus ordered him' to come from the rear to the front; but

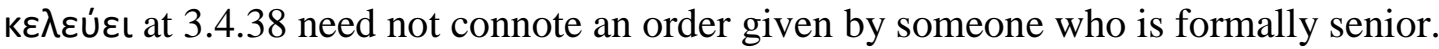


a question about a possible sortie (with one point of difference: in the Anabasis, Chirisophus' question $\pi \tilde{\omega} \varsigma \tau \imath \varsigma \tau o \nu ̀ \varsigma \not \alpha v \delta \rho \alpha \varsigma \dot{\alpha} \pi \varepsilon \lambda \tilde{\alpha}$ is spoken before Xenophon points out the spur of the mountain, while the Roman consul in Cato asks ad eum locum in hostium cuneos quisnam erit, qui ducat? after Caedicius has made his proposal). 4. The junior officer offers to lead a force up the hill himself. 5. He successfully leads a small group up the hill, observed by onlookers (both sides in Xenophon, the enemy only in Cato). 6. The rest of the army is able to make progress. More tentatively, one could also point to the presence of unusual bodily

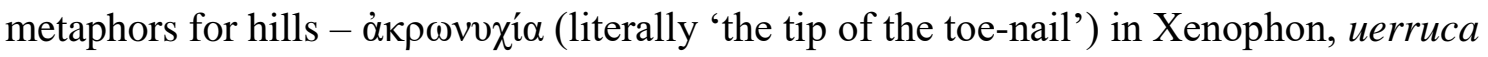
('wart') in Cato. ${ }^{8}$

As well as cumulatively amounting to a strong case for Cato's direct use of Xenophon, these similarities point up a key difference between the two texts: Caedicius volunteers for an expedition that seemingly means certain death (though unexpectedly he survives himself), whereas Xenophon's plan involves rather less risk to the lives of the participants. And this difference in turn lays further stress on Caedicius' patriotic selfsacrifice (though any possible contrast of Greek and Roman is complicated by the Leonidas comparison).

The case for Cato's use of Xenophon will be supported further in Section III, which will set out other evidence for Cato's knowledge of Xenophon. First, we turn to the passage of Livy which is modelled not just on the Caedicius episode, as other scholars have argued, but also on the same passage of Xenophon.

\section{Livy's Decius}

\footnotetext{
${ }^{8}$ On uerruca see Albrecht 1989, 25; Mariotti 1990; Holford-Strevens 2003, 248 (military slang); Briscoe 2010, 157 n. 19.
} 
The escapade of the military tribune P. Decius Mus (famous for his later deuotio) appears towards the start of Livy's account of the First Samnite War. Livy begins his account of the war with a new preface in which he announces the start of maiora ... bella, 'greater wars' that is, the succession of wars against the Samnites, Pyrrhus, and Carthage that were fundamental to the growth of Rome (7.29.1-2). He then sets an early success by one consul in Campania against the near-disaster suffered by the other consul, A. Cornelius Cossus, in Samnite territory (7.34.1). It is Decius who saves the day after Cornelius has led the army into a trap:

P. Decius tribunus militum conspicit unum editum in saltu collem, imminentem hostium castris, aditu arduum impedito agmini, expeditis haud difficilem. itaque consuli territo animi 'uidesne tu' inquit, 'A. Corneli, cacumen illud supra hostem? arx illa est spei salutisque nostrae, si eam, quoniam caeci reliquere Samnites, impigre capimus. ne tu mihi plus quam unius legionis principes hastatosque dederis; cum quibus ubi euasero in summum, perge hinc omni liber metu, teque et exercitum serua; neque enim moueri hostis, subiectus nobis ad omnes ictus, sine sua pernicie poterit. nos deinde aut fortuna populi Romani aut nostra uirtus expediet.' conlaudatus ab consule accepto praesidio uadit occultus per saltum; nec prius ab hoste est uisus quam loco quem petebat appropinquauit. inde admiratione pauentibus cunctis, cum omnium in se uertisset oculos, et spatium consuli dedit ad subducendum agmen in aequiorem locum et ipse in summo constitit uertice. (7.34.3-8)

Publius Decius, a tribune of the soldiers, espied a solitary hill, which rising above the pass, commanded the enemy's camp, and though arduous of access to an army encumbered with baggage, was not difficult for men in light marching order. He 
accordingly said to the consul, who was much perturbed: 'Do you see, Aulus Cornelius, that summit that rises above the enemy? It is the fortress of our hope and safety, if we are prompt to seize it, since the Samnites have been so blind as to neglect it. Give me no more than the first and second lines of a single legion; when with these I have mounted to the top, do you go forward fearlessly and save yourself and the army; for the enemy, exposed to all our missiles, will not be able to stir without bringing destruction on themselves. As for us, thereafter the fortune of the Roman People or our own manhood will extricate us.' Being commended by the consul and receiving his detachment, he advanced under cover through the wood, nor did the enemy perceive him till he had nearly reached the place which he wished to gain. They were then all overcome with astonishment and dread, and while they turned, every man of them, and gazed at him, the consul was given time to withdraw his army to more favourable ground, and Decius himself took his post on the top of the hill.

Under siege himself on the hill, Decius leads a night-time breakout. Finally, reunited with the main army, he proposes an immediate attack on the enemy, and a stunning success ensues. Decius' exploits have several points of similarity with the Xenophon and Caedicius episodes: in all three passages, the enemy holds a higher position until a junior officer notices a hill unoccupied by the enemy and leads a small group on a daring mission to seize it. At the same time, there are some points of difference: in particular, whereas the sorties of Caedicius and Xenophon are distractions to enable the rest of the army to move safely (in Caedicius' case, at the cost of the men who seize the hill), Decius with some bravura claims that his plan will put the enemy in a position of extreme danger, since they will be unable to stir without loss. A close analysis of the full pattern of similarity and difference will lead to the conclusion that Livy was using the version in Cato (or one very close to it) and, by a sort of 
'window reference', himself reworking the Xenophon passage that inspired Cato's version of the Caedicius story. ${ }^{9}$

The link between the Caedicius and Decius episodes has been discussed in earlier scholarship. Stephen Oakley writes that 'the stories are so similar that it is hard not to believe that one has not influenced the other; and it is obviously more likely that the later (and seemingly more celebrated) has affected the earlier' ${ }^{10}$ He further adduces as evidence that Livy himself was aware of the parallel between these episodes a speech by T. Manlius Torquatus after the Roman defeat at Cannae which argues against ransoming those Roman soldiers who were taken captive after refusing to take part in a breakout proposed by $\mathrm{P}$. Sempronius. ${ }^{11}$ Torquatus cites Decius and the tribune (here named Calpurnius) as men who led missions that were more dangerous still:

\footnotetext{
9 "A "window reference" occurs when C, who is referring to B (who in turn is referring to A), himself refers to A in order to demonstrate his awareness of B's procedure and perhaps also to correct it' (Kraus and Woodman 1997, $116 \mathrm{n}$. 63, showing that a concept developed in scholarship on Virgil (Thomas 1986, 188-9) is also applicable in historiography). 10 Oakley 1997-2005, 2.333. He further notes that 'the absence of a potential parallel narrative makes it hard to assess L[ivy]'s own artistic contribution to the telling of this tale', but that 'the great length of the episode suggests that much of its detail was due to his own imagination'.

${ }^{11}$ Decius and the First Punic War tribune are also juxtaposed at Frontinus, Strat. 1.5.14-15 (= 4.5.9-10), with the connection idem fecit, 'did the same thing'; cf. Ampel. 20.5-6, Calpurnius followed by the deuotio of the two Decii, in a chapter on qui pro populi Romani salute se optulerunt, 'those who sacrificed themselves for the sake of the Roman people'. See also nn. $19,56$.
} 
si ut auorum memoria P. Decius tribunus militum in Samnio, si ut nobis

adulescentibus priore Punico bello Calpurnius Flamma trecentis uoluntariis, cum ad tumulum eos capiendum situm inter medios duceret hostes, dixit 'moriamur, milites, et morte nostra eripiamus ex obsidione circumuentas legiones', si hoc P. Sempronius diceret, nec uiros equidem nec Romanos uos ducerem, si nemo tantae uirtutis exstitisset comes. $(22.60 .11)$

If he had said what, within the recollection of our grandsires, Publius Decius, tribune of the soldiers, said in Samnium; or what Marcus Calpurnius Flamma said, when we ourselves were young men, in the former Punic war, to three hundred volunteers whom he was leading to take a hill situated in the very midst of the enemy: 'Soldiers, let us die, and by our death set free the beleaguered legions' - if Publius Sempronius had said this, I should have deemed you no true men, to say nothing of Romans, if none had come forward to share so brave an exploit.

Livy's speaker, besides using a different name (assuming Cato offered one), makes the size of the tribune's force smaller (300 rather than 400). That the same episode is at stake, however, is confirmed by Livy's own treatment of it, which survives only in a summary:

Atilius Calatinus cos. cum in locum a Poenis circumsessum temere exercitum duxisset, M. Calpurni, tribuni militum, uirtute et opera euasit, qui cum CCC militibus eruptione facta hostes in se conuerterat. (Periochae, Book 17)

The consul Atilius Calatinus having rashly led his army into a place surrounded by the Carthaginians, escaped through the valiant services of Marcus Calpurnius, a tribune of 
the soldiers, who with three hundred men broke through the enemy and drew their attack upon himself.

Through the speech of Torquatus, Livy even offers an implicit comment on the alignment of the episodes: Torquatus wrongly implies that Decius' breakout was as suicidal as Calpurnius'. ${ }^{12}$

While the basic patterning of the narrative and its subsequent reception in Torquatus' speech support the conclusion that Livy's Decius episode has been shaped by the First Punic War episode, this conclusion does not necessarily entail that Livy was drawing specifically on the story of the tribune in Cato. One possible objection to Livy's use of Cato is the fact that Livy's own version of the tribune differed, as we have seen, with respect to both the name of the hero and the number of troops he had with him. Livy, however, need not yet have decided when he wrote the Decius episode what source he would follow for the First Punic War incident ten books later. Moreover, the differences over name and number can both be related to Cato's Thermopylae comparison. It was that comparison that led to the troops being downsized from 400 to 300 (the number of Spartans at Thermopylae). ${ }^{13}$ And as

12 Decius' subsequent breakout from the hilltop is in fact much closer to the escape orchestrated by Sempronius after Cannae - an escape by night though weary enemy lines. The focus on death fits much better his later deuotio, a self-sacrifice that ensured the safety of a Roman army (8.9). The flexible use of exempla by speakers in Livy is a major theme of Chaplin 2000.

${ }^{13}$ The smaller force gives a greater aura of heroism even without the Thermopylae resonance. The same figure appears in the Anabasis episode, but it is the number of select hoplites, not the total force Xenophon leads up the hill. It is also frequent in other narratives featuring 
for the name, if Cato omitted a name, then Livy could be read as giving Calpurnius the personal praise denied him by Cato, while if Cato did use the name Caedicius, the change in Livy's account reinforces Cato's point about the fragility of fame in Rome. ${ }^{14}$

The possibility that Livy did use Cato directly can be supported by other evidence for his knowledge of the Origines $^{15}$ as well as by the thematic weight attached to the episode of the tribune. As we have seen, Cato concluded the episode by drawing a parallel with Leonidas and reflecting on the vagaries of fame - reflections whose ideological resonance (to be discussed in Section IV) must have made the passage well-known (they are presumably what drew Gellius to the passage). A similar self-consciousness about praise appears when Livy presents Decius proposing to his men that they wait until dawn before rejoining the main Roman army:

uestrum iter ac reditum omnia saecula laudibus ferent; sed ad conspiciendam tantam uirtutem luce ac die opus est, nec uos digni estis quos cum tanta gloria in castra reduces silentium ac nox tegat. (7.36.6)

Your expedition and return shall be renowned through all the ages. But the light of day is needed for such gallantry to be seen, nor do you merit that your glorious return to camp should be accomplished in silence and under cover of night.

select forces (e.g. Thuc. 2.25.3, 3.22.7, 23.3, 4.70.2, 125.3, 6.100.1). The unreliability of the textual transmission of numbers should also be remembered (see Rubincam 2003).

${ }^{14}$ Cf. (with Holford-Strevens 2003, 249) the pathos in Gellius' addition of the variant name (Laberius) of the tribune in Claudius Quadrigarius.

${ }^{15}$ For Livy’s knowledge of Cato’s Origines, see Tränkle 1971; Briscoe 1981, 63-65. 
Decius orchestrates his own fame by waiting for the 'light' of day, and that light can be read metahistoriographically as the lucid Livian style that transmits his fame. ${ }^{16}$ This thematic link is bolstered by the shared language of salvation (rem seruare, exercitum ceterum seruauit, rem seruauerat $($ Gell. 3.7.6, 19) teque et exercitum serua, exercitum egregium populo Romano seruastis (Livy 7.34.5, 35.4)) and hope (alia nisi haec salutis uia nulla est (Gell. 3.7.8) arx illa est spei salutisque nostra, una est salus (Livy 7.34.4, 35.9)). In addition, both accounts focus on the emotions of the enemy as they watch the Roman soldiers (hostes eorum audaciam dimirantur (Gell. 3.7.12) admiratione paventibus (Livy 7.34.8)). ${ }^{17}$

The likelihood of Livy's use of Cato is strengthened by variations in the way the First Punic War episode was told. Frontinus, after giving three attested names for the tribune, presents him not seizing a hill, as in Cato, but simply making a sortie into the valley:

Is cum demissum in eam uallem uideret exercitum, cuius latera omniaque superiora hostis insederat, depoposcit et accepit trecentos milites, quos adhortatus, ut uirtute sua exercitum servarent, in mediam uallem decucurrit; et ad opprimendos eos undique descendit hostis longoque et aspero proelio retentus occasionem consuli ad extrahendum exercitum dedit. (Frontinus, Strat. $1.5 .15=4.5 .10$ )

This man, seeing that the army had entered a valley, the sides and all commanding parts of which the enemy had occupied, asked and received from the consul three hundred soldiers. After exhorting these to save the army by their valour, he hastened to the centre of the valley. To crush him and his followers, the enemy descended from

\footnotetext{
${ }^{16}$ For lux see OLD 9b ('clarity of expression, lucidity'); cf. Kraus 1994 on clariora at 6.1.3.

${ }^{17}$ Contrast Xenophon's focus on the gaze and emotions of both sides (for which cf. e.g. Livy
} 7.10.9, 8.8.10; Val. Max. 3.2.1, 23, 24). 
all quarters, but, being held in check in a long and fierce battle, they thus afforded the consul an opportunity to extricate his army.

The same version may underlie the brief summary in Ampelius, who mentions the death of the party in Siciliensi saltu, 'in a Sicilian pass', rather than on top of the hill. And Frontinus' version could well have been taken from Livy himself, one of his most frequent sources; ${ }^{18}$ if so, Livy reversed the chain of influence by making Cato's version of the Caedicius story seem derivative.

If we are right to read Livy's account of Decius against Cato's Caedicius, it is important to explore further the differences between the accounts as well as their similarities. We have already seen that Cato presents Caedicius leading his men on a suicidal mission whereas Livy gives Decius more positive aims even than Xenophon in his comparable position. That Livy's other departures from Cato also draw him closer to Xenophon raises the possibility that Livy was reshaping the story of Decius through his own reading of the episode in the Anabasis on which Cato modelled the story of Caedicius.

One difference between the Livy and Cato passages concerns the question of who is to lead the sortie. In Cato, Caedicius first proposes that the consul should send 400 men, and offers to lead the troops only in a conversation with the consul that follows immediately from his proposal. In Livy, by contrast, Decius himself takes the initiative in offering to lead a force up the hill himself, taking it for granted that he will lead the select force (cum quibus ubi euasero). Here Livy is closer to the Anabasis passage, where Xenophon offers to lead the party and is then allowed to make the final choice; at the same time, the different way in

\footnotetext{
${ }^{18}$ The following episode in Frontinus (1.5.16, the Numidian cavalry) includes a comparison with the Caudine Forks, for which cf. Livy 35.11.3.
} 
which Xenophon and Decius take the initiative contributes to Livy's forceful characterization of Decius.

Two further differences between Cato and Livy lie in their treatment of the hill and of the way it is viewed. In Cato, the hill seems to be an exposed hill within the valley overlooked by the heights which the Carthaginians have seized; in Livy, by contrast, the hill which Decius seizes commands the enemy position. ${ }^{19}$ Again, in Cato the sight of the hill (with all its strategic possibilities) is revealed first in the tribune's speech to the consul, whereas in Livy's account of Decius it is revealed in the earlier narrative (conspicit unum editum in saltu collem), despite some earlier description by the narrator of the setting. ${ }^{20}$ Given

19 uir. ill. 26.1, 39.1, by contrast, uses the phrase in superiorem locum euasit both of the tribune in Sicily and of Decius, suggesting that they made the same response to their dangerous positions (though superiorem need not be relative to the Carthaginians); cf. Zonaras 8.12, where the tribune seizes one of the surrounding hills which the Carthaginians had overlooked owing to its steepness. Note also the suggestion by Russell 2001, 3.368 n. 68, that the line quoted by Quintilian 8.3.48, saxea est uerruca in summo montis uertice ('there is a rocky wart upon the mountain's head'), may come from a historical play covering the First Punic War episode (Courtney 1999, 75, even raises the possibility that the line could come from Cato, but notes that Cato's account suggests a hillock). There may be some confusion in Gellius' paraphrase (possibly reflecting Cato's original account): if the enemy have surrounded the Romans, what are the safe heights to which the rest of the Roman army moves while the Carthaginians fight the Romans on the hill?

${ }^{20}$ in saltum caua ualle peruium circaque insessum ab hoste (Livy 7.34.1: 'into a forest which was penetrated by a deep defile, and was there beset on either hand by the enemy'). Decius' distinctive vision is stressed by Jaeger 1999, 185. The hill stands out against the otherwise stereotypical Livian ambush topography (on which see Horsfall 1982, 50). 
the way in which Gellius glosses the unusual phrase uerrucam illam, it seems likely that this difference was found in Cato's original rather than simply resulting from Gellius' abridgement (the illam need not presuppose prior mention of the hill; rather, it can be read as effectively placing readers in the consul's position, as a new feature is pointed out).

In departing from Cato's treatment of the hill, Livy was again moving closer to Xenophon. In the Anabasis passage, too, the unoccupied hilltop lies above the enemy position, and, while the narrator has given some topographical indications, ${ }^{21}$ it is first mentioned as it is seen by the character Xenophon - the first instance of what becomes one of the distinctive narrative features of the Anabasis. ${ }^{22}$ The link between the two authors is strengthened by their distinctive use of the historic present: ò å is a striking feature of the Anabasis by comparison with Xenophon's other works, ${ }^{23}$ while conspicit is found only here in the extant parts of Livy (the plural conspiciunt is found three times $(10.34 .7,10.34 .8$, 21.33.2) and the present passives conspicitur and conspiciuntur a further three times (9.2.10, 23.19.11, 37.23.1)). Given that the historic present with uideo is somewhat more common in Livy, his conspicuous use of conspicit reinforces rather than detracts from the

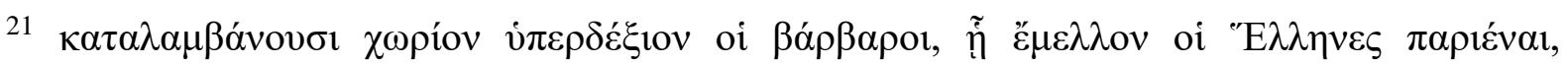

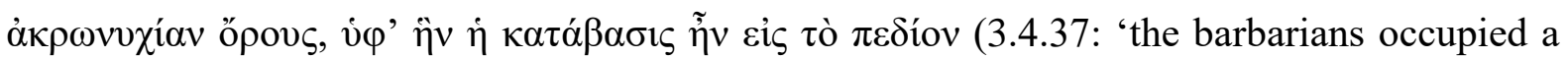
high position above the road by which the Greeks were to pass, a spur of the mountain, namely, along the base of which ran the route leading down into the plain').

${ }^{22} \operatorname{Rood} 2014,78-84$.

${ }^{23}$ The historical present ò $\rho \tilde{a}$ occurs five times in Xenophon, all in Anab., while plural ópw̃ is found seven times, five of them in Anab. 
intertextuality. ${ }^{24}$ This shared stress on sight has a thematic significance. Livy is picking up Xenophon's foregrounding of sight as one of the hallmarks of the good leader. ${ }^{25}$

Another possible difference between Livy and Cato may lie in the aftermath of the sorties. Gellius' paraphrase of Cato does not make clear whether the Romans subsequently withdrew from the valley or proceeded along the route they had originally planned ${ }^{26}$ at most, it shows that the Romans were at least able to recover the bodies of Caedicius' men (the Romans rather than the Carthaginians must be the subject of cognouere, 'recognised', in

${ }^{24}$ The stress on sight in our passage (in 7.34 also found in uidit (2); uidesne (4); est uisus (7); in se uertisset oculos (8); uidetis (13), cf. 7.36 .8 coniectis in eum omnium oculis) is strengthened by contrast with blindness language (Oakley 1997-2005, 2.334) and by the careful delineation of the transition from day to night.

${ }^{25}$ Given the links with Cato, it may be pertinent to note the strong stress on Cato as viewer in Livy's account of his Spanish campaign: consul omnia oculis perlustrat ... ad sinistram partes infrequentes uidet (34.15.6: 'the consul scanned everything with his gaze ... he saw that there were few defenders at the left gate'; cf. also 34.14.7, 15.3, 20.7). Here the historical present uidet is followed by new information, as with conspicit in the Decius narrative; there is also a close verbal link with a slightly later stage of the Decius narrative (7.35.15: haec omnia ... perlustrauit, 'he scanned all these matters' [viz. the position of the enemy troops prior to the breakout]).

${ }^{26}$ Withdrawal is implied by Frontinus, Strat. 1.5 .15 (occasionem consuli ad extrahendum exercitum dedit, 'afforded the consul an opportunity to extricate his army') and Zonaras 8.12

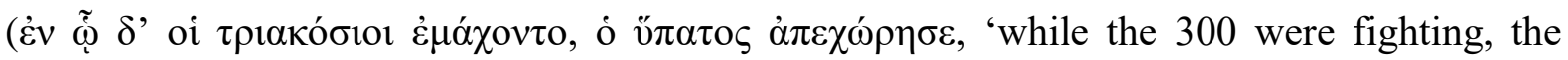
consul withdrew'); continuation by Oros. 4.8 .2 (donec Romanus exercitus obsessas angustias hoste non urguente transiret, 'until the Roman army crossed the besieged narrows, with the enemy not pressing them'). 
Gellius' summary). Livy's Romans, by contrast, like Xenophon's Greeks, are able to proceed in the route they had been intending to take.

The Xenophontic resonance may continue in the scene where Decius proposes that his men, now stranded on the hilltop, try to regain the main army by breaking through the enemy lines. Decius here puts his plan to a vote $(7.35 .2,12)$, which is unanimous $(7.36 .1)$ - an odd 'exercise in military democracy' ${ }^{27}$ in a Roman context, but similar to the votes (admittedly by hands rather than by changing position, as in Livy's nocturnal scene) earlier in the Anabasis $(3.2 .9,33,38)$.

Even if this further link is discounted, the intersections between the three accounts suggest not just that both Cato and Livy made use of Xenophon but also that Livy's reworking of Xenophon was itself picking up Cato's use. Livy's response to both authors gains further point, moreover, in the light of Decius' later deuotio. Decius' career mirrors the progression from Xenophon's bold exploit (which ensures survival) to the self-sacrifice of Cato's Caedicius, and Decius too is glorified by association with Cato's Thermopylae comparison. $^{28}$

The significance both of the Thermopylae comparison and of the intertextuality between Xenophon, Cato, and Livy will be explored further in the final section. First, however, it will be helpful to support the case for the use of Xenophon by exploring more generally the evidence for Roman historians' knowledge of Xenophon. I will set out the evidence first for Cato, then for Livy.

\section{Xenophon and Roman historiography}

\footnotetext{
${ }^{27}$ Pelling 1999, 339.

${ }^{28} \mathrm{I}$ am indebted to the anonymous referee for these points.
} 
The claim that Cato made use of the Anabasis may be supported by broader evidence of the popularity of Xenophon in Roman culture in the second and first centuries BC. According to Cicero, Cato's contemporary Scipio Aemilianus admired Xenophon's precepts on generalship (Tusc. 2.62; $Q$ Fr. 1.1.23), and Cato himself also admired his works for their utility (Sen. 59). He may well have used Xenophon's Oeconomicus in De agricultura,${ }^{29}$ and an imitation of the start of Xenophon's Symposium has also been detected in the Origines (FRHist 5 F2) ${ }^{30}$ It is generally supposed that the Anabasis was less familiar to Roman readers at this time than the Cyropaedia and Xenophon's Socratic works, but there is still no reason to doubt that it was read alongside Cyropaedia as a model of good leadership - particularly of leadership shown in overcoming defeat or disaster and extricating armies from difficult situations.

Other fragments of Cato support the case for direct influence of the Anabasis. It is known that Cato included direct reports of his own speeches in the closing sections of the Origines, and Xenophon's practice in the Anabasis has been seen as a possible model. ${ }^{31}$ There are also some (previously unnoticed) signs of linguistic influence. The evidence for this influence comes from Nonius Marcellus, a Latin grammarian probably from the fourth century AD, who cites two river descriptions from the Origines (Non. 151M=221L; FRHist 5 F99, 111): Cato originum u: origine fluuium Naronem, magnum, pulchrum, pisculentum; et libro uii: fluuium Hiberum; is oritur ex Cantabris, magnus atque pulcher, pisculentus ('Cato in Origins, book 5: the river Naro from its source, large, beautiful, full of fish. And in book 7:

${ }^{29}$ Powell 1988, 223.

${ }^{30}$ Dillery 2009, 94 (with further references in n. 1). Woodman 2014, 68, sees a 'window reference' to Xenophon via Cato at Tac. Agric. 1.1. For Cato's Hellenism more broadly, see Astin 1978, 157-181; Gruen 1992, 52-83; Livy has him allude in a speech to the myth of the Lemnian women (34.2.7).

${ }^{31}$ Marincola 1997, 194. 
the river Ebro; it rises among the Cantabrians, large and beautiful, full of fish'). The technique of repetition seen in the use of magnus atque pulcher is the same as that found in

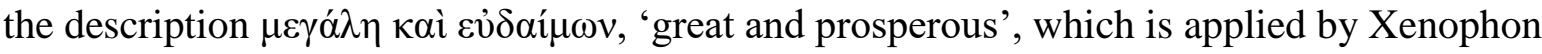
in the Anabasis to cities $(1.2 .6,7,20,23,1.4 .2,11,1.5 .10,2.4 .28,4.7 .19)$, often in

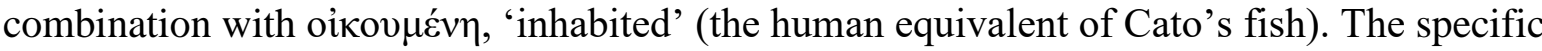

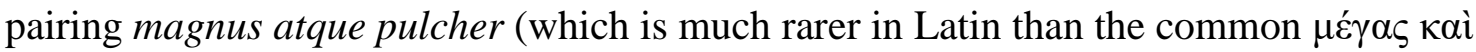
$\kappa \alpha \lambda o ́ \varsigma$ in Greek ${ }^{32}$ ) also plays off Xenophon's description of the River Teleboas in Armenia:

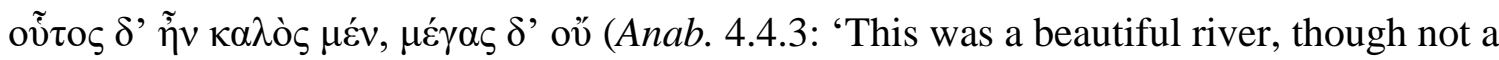
large one'). ${ }^{33}$ Cato's river descriptions even pick up Xenophon's sporadic attention to rivers with fish. ${ }^{34}$

${ }^{32}$ It is quite possible that there were other occurrences of magnus atque pulcher in Cato; that Nonius cites two passages of Cato under pisculentus suggests at most that he knew of no other instances of that word in the Origines. Sallust's phrase maxumum atque pulcherrumum at $B C 20.3$ is probably imitated from Cato (McGushin 1977: 138). The adjectives are also paired in an ethnographic setting at Varro Rust. 2.3.4: fieri dant operam ut ex insula Melia capras habeant, quod ibi maximi ac pulcherrimi existimantur fieri haedi ('Some owners are even careful to import she-goats from the island Melia, because it is thought that the largest and finest kids are produced there'); similarly Cic. Verr. 2.4.37, 119. The Ganges is called

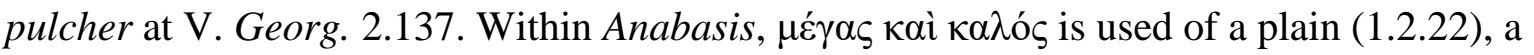
$\pi \alpha \rho \alpha ́ \delta \varepsilon 1 \sigma o \varsigma(1.4 .10,2.4 .14)$, and of Persian and Median women (3.2.25).

${ }^{33}$ This description was admired in antiquity ([Demetr.] De eloc. 6, 121). For beauty and size as criteria in descriptions of rivers, cf. Paus. 8.25.13; Aristid. 36.125.

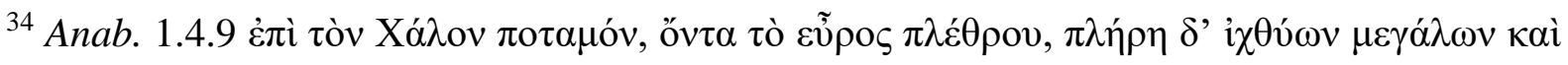
$\pi \rho \alpha \varepsilon \dot{\omega} \omega v$ ('to the Chalus river, which is a plethrum in width and full of large, tame fish');

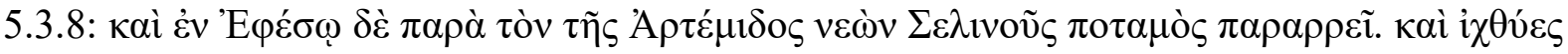


The case for knowledge of the Anabasis is strengthened by the fact that the Caedicius story is not the only instance where Xenophon has influenced the telling of an episode in the First Punic War. Immediately after the passage quoted above, the narrator describes how the character Xenophon was abused by a hoplite for riding on horseback while the hoplite was struggling uphill with a heavy shield. Xenophon promptly dismounted, removed the man's shield, and started uphill in his place (3.4.44-49). Exactly the same story is told by Diodorus (23.14.2) of the Spartan mercenary general Xanthippus who served on the Carthaginian side in the early stages of the First Punic War. The fame of this episode in the Anabasis is also attested in Greek and Roman collections of stratagems in the first two centuries AD: the episode of Xenophon dismounting is one of the four episodes from the Anabasis picked out in Frontinus' Strategemata (4.6.2), while the immediately preceding episode of Xenophon's sight of the hill is one of four episodes from the Anabasis mentioned in Polyaenus' Strategemata $(1.49 .3){ }^{35}$

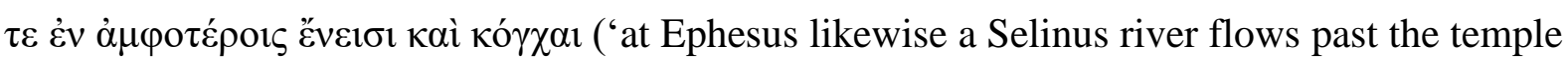
of Artemis. In both streams, moreover, there are fish and mussels').

${ }^{35}$ Given that both Frontinus and Polyaenus mention the Centrites crossing (Anab. 4.3), it is evidently possible that their citations both derive from an earlier collection. The dismounting

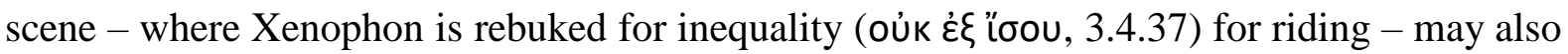
be evoked in passages in Caesar and Sallust where a general removes horses to equalize the danger: Caes. BG 1.25.1 omnium ex conspectu remotis equis, ut aequato omnium periculo spem fugae tolleret ('with everyone's horses sent out of sight, thus to equalize the danger of all and to take away hope of flight'); Sall. Cat. 59.1 remotis omnium equis quo militibus exaequato periculo animus amplior esset ('after sending away all the horses in order to increase the soldiers' courage as a consequence of the equalized danger'); cf. Grillo 2012, 74. 
We may now turn to the question of Livy's knowledge of Xenophon. Livy does not name Xenophon in any of the extant parts of his work, though the Cyropaedia is surely in mind when he alludes to flattering Greek accounts of the elder Cyrus (9.17.6). ${ }^{36}$ Nor are any traces of Xenophon's historical writings detected in Latin authors between Cicero and Tacitus in Münscher's (still standard) 1920 monograph on Xenophon's reception in antiquity. ${ }^{37}$ Nonetheless, one or two Xenophontic intertexts in Livy have been proposed by scholars since then. ${ }^{38}$ The familiarity of the Anabasis in the first century BC may further be suggested by Caesar's possible use of Xenophon as a model for his third-person self-presentation in his Commentarii. ${ }^{39}$ Further evidence of interest in Xenophon as a model for participant narratives can be found in Cicero's comment that Q. Lutatius Catulus wrote a book on his consulship and achievements molli et Xenophontio genere ('in a gentle, Xenophontic style'), according to Cicero (Brut. $132=$ FRHist $19 \mathrm{~T} 1$ ) and in Jacoby's suggestion in his commentary on FGrH 197 F1 that the allusion to the Anabasis at Plut. Ant. 49.5 is derived from Q. Dellius, a participant in Antony's Parthian expedition. ${ }^{40}$ Interest in Xenophon's status as an

${ }^{36}$ Cf. Cicero's praise of the Cyropaedia ( $Q$ Fr. 1.1.23).

${ }^{37}$ Münscher 1920, 93; following Münscher, Luraghi 2017, 99, writes that 'Tacitus is the first Roman historian who certainly read [the Anabasis]'.

${ }^{38}$ Briscoe 1993, n. on 31.31.18, for an echo of Hell. 7.4 .40 (though this could come through Polybius); Morello 2003, 301-304.

${ }^{39}$ See Costantini 1993; also Pelling 2013 for a careful discussion that brings out some important differences. Note also that Suet. Caes. 87 presents Caesar as a reader of the Cyropaedia, while Reggi 2002, 73-74, sees echoes of Hellenica in the Bellum Civile. 40 Pelling 2002, 15, with n. 97, sees this passage as one of a number of Xenophontic flourishes and suggests that these are to be attributed to Plutarch. It could also be case the Plutarch added a Xenophontic flourish to an account that was already moulded by Xenophon, 
autobiographical writer is also shown by the way in which Xenophon's famous dream (Anab. 3.1.11-12) is treated by Cicero in the De divinatione: Cicero's brother Quintus is made to proclaim his faith in the dream's historicity, but in a way that suggests he is protesting too much. $^{41}$

The proposed 'window reference' to Xenophon in Livy can be supported by David Levene's convincing analysis of an episode in Livy's narrative of the Second Punic War. Levene argues that Livy's account of Scipio's military preparations after the capture of New Carthage (26.51.7-8) rewrites Polybius - who made an overt allusion to Xenophon's account

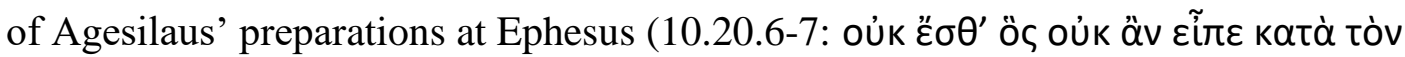

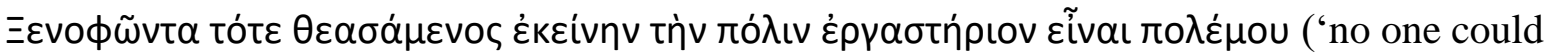
have helped when he saw that town saying, in the words of Xenophon, that it was "a workshop of war"'), alluding to Hell. 3.4.16-18) - while adding more direct linguistic echoes of Xenophon that are not found in Polybius: Livy 'rewrites Polybius in such a way that his in other words as a 'window reference'. There may also have been antecedents for Xenophontic colouring in accounts of Asiatic inland expeditions such as Manlius' against the Gallograeci (e.g. the sources for Livy 38.13-27).

${ }^{41}$ Div. 1.52: Xenophon Socraticus (qui uir et quantus!) in ea militia qua cum Cyro minor perfunctus est sua scribit somnia, quorum euentus mirabiles exstiterunt. Mentiri Xenophontem an delirare dicemus? ('That disciple of Socrates, Xenophon — and what a man he was! - records the dreams he had during his campaign with Cyrus the Younger, and their remarkable fulfilment. Shall we say that Xenophon is either a liar or a madman?'). The dream was also cited by Lucian in a defence of his own account of a dream (Somn. 17). For interest in Xenophon's self-presentation, cf. also Plut. Mor. 345E, where Xenophon is said to have published the Anabasis under the pseudonym Themistogenes to make his own selfpresentation more acceptable. 
Scipio looks more like Xenophon's Agesilaus than Polybius' did', and 'the connection between the two literary texts ... mirrors a similar connection in the real world' (insofar as Scipio could have been directly influenced by the example of the historical Agesilaus as portrayed by Xenophon). ${ }^{42}$

My argument here has presented Livy rewriting Cato in a similar way to the rewriting of Polybius posited by Levene. Even though there is no question of imitation on the part of the agents in real life (as in Levene's example), this article provides further support for Levene's bold reading of Livy's narrative technique, suggesting that he shows a virtuosity in his account of the Samnite Wars similar to that found in the ten books devoted to the Second Punic War.

\section{The uses of Xenophon}

The argument of the previous section supports the possibility that both Cato and Livy could have been aware of Xenophon's Anabasis themselves and have expected at least some of their readers to be aware of it. It is time now to consider how awareness of the Xenophontic parallel affects the interpretation of their works.

Both authors' use of Xenophon develops the engagement with Greece in Cato's comparison of Caedicius and Leonidas. On the surface, that comparison involves two patriotic sacrifices and points to a cultural difference in modes of commemoration. But Cato ends by undermining that claim that Leonidas performed 'a like exploit' (simile ... fecit) by insisting that the tribune 'had done the same thing and saved the state' (idem fecerat atque

${ }^{42}$ Levene 2010, $92-5$ (quotations from 94 and 95). I would add that the Hellenica passage is also echoed in Diodorus' account (14.41.1-3) of Dionysius' preparations for war against Carthage. 
rem seruauerat). These words pick up the final conclusion of the main narrative (exercitum ceterum seruauit, 'he saved the rest of the army') before the introduction of the Thermopylae parallel. The echo suggests that the atque introduces a supplement: Cato attaches the language of salvation to Caedicius rather than Leonidas, obscuring the fact that Leonidas was aware of an oracle which dictated that the death of a king was required for the survival of Sparta (Hdt. 7.220) - and obscuring, too, the use of the Anabasis, a work which is itself dominated by the language of salvation. ${ }^{43}$ Cato in this way elevates Roman deeds by suggesting that they match and even surpass one of the central events of Greek history. ${ }^{44}$ Like the Thermopylae comparison, the use of Xenophon operates teleologically to present the Romans as the heirs of Greece in the defence against barbarism. ${ }^{45}$ The chain of matching scenes (Xenophon, Cato, Livy) aligns the Romans with the Greeks and their adversaries, the Carthaginians and Samnites, with the Persians. In the case of Carthage, the implied equation with Persia dates back to the fifth century BC, when Greek Sicilians presented themselves as defenders against barbarism in much the same way as their fellow

${ }^{43}$ For $\sigma \omega \tau \eta \rho i ́ \alpha$ 'survival' as a new war aim from the beginning of Anabasis 3 (when Xenophon's own leading role begins), see Dillery 1995, 69-70.

${ }^{44} \mathrm{Cf}$. the similar thought at Val. Max. 3.2.22, where a little known Roman parallel is compared with the valour shown by the Athenian Cynegirus at Marathon, the fame of which has been spread by Greek praise. For the Thermopylae comparison, cf. Florus $1.18(=2.2) .13-$ 14, Ampel. 20.5; also Sen. Ep. 82.20-22 (if alluding to our scene: cf. Cato F114 = Cic. Sen. 75, Tusc. 1.101).

${ }^{45}$ Cf. the terms in which Elliott 2010, esp. 150, and 2013, 233-294, analyses Ennius' use of Homer. Thermopylae is also a prominent backdrop to the noble death of the 306 Fabii at Cremera (Livy 2.48-50), itself part of a broader trend of Greek influence on early Roman history (for which see e.g. Scapini 2011). 
Greeks in the eastern Aegean; this construction of Carthaginian identity was then taken on by the Romans in the third century. ${ }^{46}$ Similarly the Samnites' alignment with Persia is part of a broader cultural grid, bolstered within Livy's work by hints of their quasi-oriental opulence as well as by a geographical parallel later drawn between Thermopylae and the Apennines $(36.15 .6) .^{47}$

Roman self-image is also implicated in the presentation of military leadership and hierarchy that is central to the episodes in Cato and Livy. Evoking Xenophon's story of his own heroic leadership enabled comparisons and contrasts to be made between discrete historical events, contributing, as we have seen, to the characterization of the brash Decius. In Livy, indeed, the Decius story fits a pattern found elsewhere in the surrounding narrative as well as in later sections of the text: ${ }^{48}$ thus he attributes to the initiative of a Numidian cavalry commander a scheme that enables the Romans to draw off the enemy from a blocked pass (35.11.3-4, a passage where the memory of Caudine Forks disaster is explicitly evoked). Such stories of junior officers showing initiative perhaps helped to dissolve tensions in the markedly hierarchical Roman society: they can be seen as variants on the pattern of spatial

${ }^{46}$ See Rood (forthcoming) for the Carthage/Persia equation, with further bibliography; and Russo 2010 for its use in Roman anti-Carthaginian propaganda. Cf. Levene 2010, 94 for Carthage and Persia as linked via Livy's use of Xenophon.

${ }^{47}$ For barbarization of the Samnites, see more broadly Dench 1995.

${ }^{48}$ Cf. Manlius' taking the initiative in responding to a Gallic challenge (7.10); the flip-side is shown by Manlius' disobeying his father's orders when he responds to a later challenge (8.7), leading to his execution. Popov-Reynolds 2010 reads the Cato passage against Livy's presentation of single soldiers as saviours (though she does not discuss Decius). Bold tribunes from Cato's own lifetime are found at Livy 41.2.9 and perhaps Ennius 391-8 Skutsch; and see below on Cato himself. 
obstacles surmounted through either divine epiphany or surprise external help ${ }^{49}$ - that is, as part of a class of stories that bolsters the established order by stressing the help it receives from above or below.

Xenophon's original story and the twists provided by Cato and Livy offer a strong illustration of the roles played by disaster and recovery in both Greek and Roman ideology. ${ }^{50}$ In Livy, as we have seen, Decius and Calpurnius (Cato's Caedicius) are invoked in a speech after Cannae (22.60.1) - the narrative context chosen by Polybius for his book-length analysis of the elements in the Roman constitution that enable Rome to recover from defeat. It could also be argued that shared intertextual links can support intratextuality: there are, for instance, verbal echoes between Decius' escape and the Caudine Forks disaster. ${ }^{51}$

Historiographical self-definition, too, is at stake in the Roman use of Xenophon. In Cato, the swift movement from one Greek paradigm (Xenophon) to another (Herodotus) can be seen as a sign of self-conscious virtuosity. ${ }^{52}$ In Livy, the aspiration to historiographical

${ }^{49}$ For epiphany, cf. e.g. Hdt. 4.179.2 (Triton appearing to Jason); for subordinates or outside saviours, Hdt. 1.75.4 (Thales enabling the crossing of the Halys), 7.213.1 (revelation of the Thermopylae pass); Sall. Jug. 93 (a Ligurian soldier catching snails finds a means of entering a fortress). Cf. Welch 1998 on brave centurions in Caesar's Bellum Gallicum.

${ }^{50}$ See recently Clark 2014.

${ }^{51}$ For intratextual links see e.g. Lushkov 2015, 80-81. The account of the mood among the Roman soldiers after they are trapped might be compared with Anab. 3.1.2-3 (cf. e.g. the shared motif of a lack of sleep and food at Anab. 3.1.3 and Livy 9.3.4) - though various elements are common to many such descriptions.

52 Cato's virtuosity would be greater if the Ten Thousand were already linked with Thermopylae in the historiographical tradition: they are explicitly so linked at Diod. 14.25.24, where their response to a demand that they hand over their weapons is compared with 
virtuosity is greater still. It is not just that he seeks to surpass Cato in the way he draws on the dramatic power of Xenophon's narrative. He also sets his engagement with Xenophon alongside allusions to both Thucydides and Herodotus. The Decius episode follows soon after two passages with a Thucydidean resonance: the delayed preface in which Livy emphasizes the importance of the ensuing narrative (cf. Thuc. 1.23) and the account of the origins of the Samnite war (7.30), which includes clear echoes of Thucydides' Corcyra debate. ${ }^{53}$ It is in turn followed by an episode with a Herodotean resonance: some Romans are tempted by the possibility of exploiting their victory and settling in Campania (7.38), rather as, in Herodotus' closing anecdote, the victorious Persians propose to settle in a more fertile part of Asia (9.122). Livy thus follows up his programmatic amplificatio by evoking the three canonical Greek historians, offering in the process a (necessarily slanted) reading of their definitive qualities: the political analysis of Thucydides, the bravura battle narrative of Xenophon, the ethnographic and environmental interests of Herodotus. ${ }^{54}$

Cato's engagement with Greek predecessors also questions the commemorative function of historiography. His Thermopylae comparison may be taken to imply either that

Leonidas' response to a similar demand, and this comparison may well be derived from Ephorus.

53 Oakley 1997-2005, 2.294, with further references. The delayed preface may also evoke Virg. Aen. 7.37-45 (depending on the chronology).

${ }^{54}$ I do not mean to imply that Livy is here in competition with Cato's allusions to Xenophon and Herodotus: the technique of different models being imitated in close succession is itself common in Latin historians, and we do not anyway know whether allusions to other historians were juxtaposed with the Caedicius episode in Cato. 
the absence of excessive praise of individuals was a positive aspect of Roman culture ${ }^{55}$ or else that his own work provided appropriate praise. ${ }^{56}$ The first reading can be supported by the apparent infrequency of personal names in the Origines as well as by the contrast between the ornate, alliterative language Cato uses for the Greeks' laudatory practices and the closing cadence on the fate of the tribune, which has the 'grandiose simplicity of an inscription'. ${ }^{57}$ The second reading can be supported by Cato's stress in another fragment on the songs sung by early Romans at banquets which told of clarorum uirorum laudes atque uirtutes, 'the merits and glorious deeds of famous men' (F113 = Cic. Tusc. 4.3$)$, if these songs are seen as 'an earlier expression of his own exemplaristic and pedagogic approach to historiography'. ${ }^{58}$ And both readings can appeal to an ambiguous generalization attributed in the Historia Augusta to Sallust, Cato, and Gellius: omnes omnium uirtutes tantas esse quantas uideri eas

${ }^{55}$ Samotta 2012, 358-360, concluding that 'Cato evokes the images of a collective Roman strength which multiplies the Greek ideal of aristeia and shows the Romans' down-to-earth approach with regard to the employment of manpower' (360). For a similar stress on the collective in Cato, see Albrecht 1989, 28; Gotter 2009, 111-112, citing Cato's argument (F131 = Cic. Rep. 2.2) that Rome was superior to Greek states because its constitution was not the creation of a single man (but, against this, Cato may rather be highlighting the contribution of individual Romans over time).

${ }^{56}$ Astin 1978, 233 n. 63 is uncertain. Chassignet 1986, 89 n. 6 contrasts Cato's focus on the tribune's lack of fame with Pliny's stress on his receipt of the corona graminea (NH 22.11) a distinction shared with Livy's Decius (7.37.2).

${ }^{57}$ Albrecht 1989, 31-32.

${ }^{58}$ Zorzetti 1990, 303-304; cf., more complexly, Sciarrino 2004. Cornell 2009, 35 n. 81 warns that Cato's aim may have been to offer a contrast his own history to works where named individuals were overtly praised. 
uoluerint eorum ingenia qui unius cuiusque facta descripserint (F126 = [Vopisc.] Prob. 1.1: 'the virtues of all men are only as great as they have been made to seem by the genius of those who have described the deeds of each one'). The ambiguity here is whether the power of the written word in determining the way deeds are commemorated is to be celebrated or decried. However these passages are read, a further level of ambiguity is added to Cato's concern with praise by the intertextuality with Xenophon: that the Roman deed which is held up against the achievement of Leonidas is itself modelled on a Greek source paradoxically reinforces the point that Roman valour has not been fairly commemorated. This ambiguity over the role of praise in the Roman tradition serves in turn as foil to the unambiguous achievements of the Romans in the sphere of action.

Cato's use of Xenophon itself raises the question of self-praise. Livy caps his account of Cato's Spanish campaign in his consulship by referring to Cato as haud sane detractator laudum suarum (34.15.9: 'a man not much inclined to be grudging in his own praise'). ${ }^{59}$ Plutarch speaks in a similar vein of Cato's narrative of his own deeds in the Roman victory over Antiochus III in $191 \mathrm{BC}-$ at the resonant location of Thermopylae: ${ }^{60}$

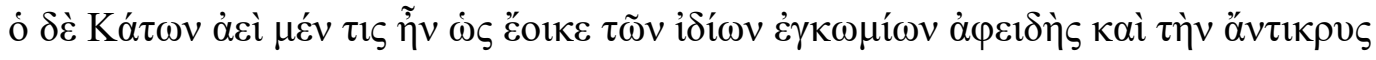

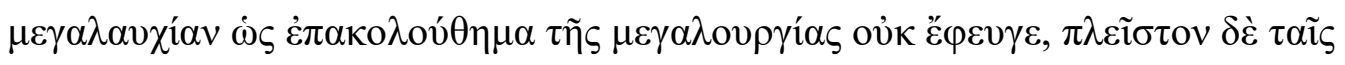

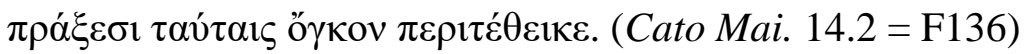

\footnotetext{
59 This claim is followed in some manuscripts by a recapitulation (34.16.1-2) of 'the three praiseworthy acts he is credited with having performed that day' (tria eo die laudabilia fecisse putatur). Some editors dismiss this passage as an interpolation; at the very least it shows that the rhetoric of praise was picked up in the course of the text's transmission.

${ }^{60}$ Cf. Calboli 1996, 11-12; Samotta 2012, 360.
} 
Cato, who, it seems was never one to be reticent about his own praises, and could never resist following up a great achievement with an openly boastful account of it, gives a very inflated version of these events.

Cato's role as a subordinate officer in that battle may itself be linked with the three passages discussed above: he helps the Romans surmount Antiochus' blocking of the pass by leading them round by the path earlier used by the Persians (Livy 36.17.11, cf. 16.7; Plut. Mar. 13.1, with a much stronger stress on Cato's own initiative). Cato's implicit allusion to Xenophon, then, can be read as a proleptic justification for what Cato himself will go on to do when he describes his own career in the Origines. ${ }^{61}$

This article has pointed to similarities between a vivid episode in Xenophon's Anabasis and two famous episodes in Roman Republican history, Cato's account of Caedicius' selfsacrifice in the First Punic War and Livy's account of Decius' breakout in the First Samnite War. Rather than seeing the three episodes as simply variants of a basic story-pattern of a junior officer saving the day, it has argued that the links between them are robust enough for a chain of literary influence and re-modelling to be posited and suggested a number of areas (self-definition in relation to Greece, military leadership and hierarchy) where the use of Xenophon catered well to Roman ideology. Xenophon, it seems reasonable to conclude, should be allotted the prominent position in approaches to intertextuality in the Roman historians that his canonical status in antiquity should lead to expect. ${ }^{62}$

${ }^{61} \mathrm{I}$ am indebted to David Levene for the formulation used in this sentence.

${ }^{62}$ I am extremely grateful to Rhiannon Ash, Andrea Capovilla, Chris Kraus, David Levene, Stephen Oakley, Chris Pelling, and the anonymous referee for their comments. 


\section{Bibliography}

Albrecht, M. von. 1989. Masters of Roman Prose from Cato to Apuleius: Interpretative Studies (Leeds).

Astin, A.E. 1978. Cato the Censor (Oxford).

Briscoe, J. 1981. A Commentary on Livy, Books XXXIV-XXXVII (Oxford).

Briscoe, J. 1993. A Commentary on Livy, Books XXXI-XXXIII (Oxford).

Briscoe, J. 2010. The Fragments of Cato's Origines, in: Dickey, E. Chahoud, A. (eds.)

Colloquial and Literary Latin (Cambridge), 154-160.

Calboli, G. 1996. Die Episode des Tribunen Q. Caedicius (Cato, Orig. Frg. 7-43 Peter), Maia $48,1-32$.

Cawkwell, G.L. 2004. When, How and Why did Xenophon write the Anabasis?, in: Lane Fox, R. (ed.), The Long March: Xenophon and the Ten Thousand (New Haven), 47-67.

Chaplin, J.D. 2000. Livy's Exemplary History (Oxford).

Chassignet, M. 1986. (ed.) Caton: Les Origines (fragments) (Paris).

Clark, J.H. 2014. Triumph in Defeat: Military Loss and the Roman Republic (New York and Oxford).

Cohee, P. 2007. Gell. 3.7.16 (Cato Orig. 83 Peter): cum uno, Hermes 135, 365-369.

Costantini, M. 1993. Xénophon ou l'art de la bonne distance, in: Poli, D. (ed), Cultura in Cesare (Rome), 137-148.

Cornell, T.J. 2009. Cato the Elder and the Origins of Roman Autobiography, in: Smith, C.J. (ed.), The Lost Memoirs of Augustus: and the Development of Roman Autobiography (Swansea), 15-40.

Courtney, E. 1999. Archaic Latin Prose (Atlanta).

Dench, E. 1995. From Barbarians to New Men: Greek, Roman, and Modern Perceptions of Peoples of the Central Apennines (Oxford). 
Dillery, J. 1995. Xenophon and the History of his Times (London).

Dillery, J. 2009. Roman Historians and the Greeks: Audiences and Models, in: Feldherr, A.

(ed.), The Cambridge Companion to the Roman Historians (Cambridge), 77-107.

Elliott, J. 2010. Ennius as a Universal Historian: The Case of the Annales, in Liddel, P.,

Fear, A. (eds), Historiae Mundi: Studies in Universal Historiography (London), 148-161.

Elliott, J. 2013. Ennius and the Architecture of the Annales (Cambridge).

Goldberg, S.M. 2005. Constructing Literature in the Roman Republic: Poetry and its Reception (Cambridge).

Gotter, U. 2009. Cato's Origines: The Historian and his Enemies, in: Feldherr, A. (ed.) The Cambridge Companion to the Roman Historians (Cambridge), 108-122.

Grillo, L. 2012. The Art of Caesar's Bellum Civile (Cambridge).

Gruen, E.S. 1992. Culture and National Identity in Republican Rome (Ithaca).

Holford-Strevens, L. 2003. Aulus Gellius: An Antonine Scholar and his Achievement (Oxford).

Horsfall, N. 1982. The Caudine Forks: Topography and Illusion, PBSR 50, 45-52.

Jaeger, M. 1999. Guiding Metaphor and Narrative Point of View in Livy's Ab Vrbe Condita, in Kraus 1999, 169-195.

Kraus, C.S. 1994. (ed.) Livy: Book VI (Cambridge).

Kraus, C.S. 1999. (ed.) The Limits of Historiography: Genre and Narrative in Ancient Historical Texts (Leiden).

Kraus, C.S. Woodman, A.J. 1997. Latin Historians (Oxford).

Krebs, C.B. 2006. Leonides Laco quidem simile apud Thermopylas fecit: Cato and Herodotus, BICS 49, 93-103.

Levene, D.S. 2010. Livy on the Hannibalic War (Oxford). 
Luraghi, N. 2017. Xenophon's Place in Fourth-Century Greek Historiography, in: Flower, M.A. (ed.), The Cambridge Companion to Xenophon (Cambridge), 84-100.

Lushkov, A.H. 2015. Magistracy and the Historiography of the Roman Republic (Cambridge).

McGushin, P. 1977. C. Sallustius Crispus, Bellum Catilinae: A Commentary (Leiden). Mariotti, I. 1990. Verruca “locus editus”. MH 47, 82-86.

Marincola, J. 1997. Authority and Tradition in Ancient Historiography (Cambridge).

Morello, R. 2003. Place and Road: Neglected Aspects of Livy 9.1-19, in: Deroux, C. (ed.), Studies in Latin Literature and Roman History XI (Brussels), 290-306.

Oakley, S.P. 1997-2005. A Commentary on Livy: Books VI-X, 4 vols (Oxford).

Pelling, C.B.R. 1999. Epilogue, in: Kraus 1999, 325-357.

Pelling, C.B.R. 2002. Plutarch and History (London and Swansea).

Pelling, C.B.R. 2013. Xenophon and Caesar's Third-Person Narratives - Or Are They?, in:

Marmodoro, A., Hill, J. (eds.), The Author's Voice in Classical and Late Antiquity (Oxford), 3976.

Popov-Reynolds, N. 2010. The Heroic Soldier as Exemplum in Cato and Livy, in:

Polleichtner, W. (ed.), Livy and Intertextuality: Papers of a Conference Held at the University of Texas at Austin October 3, 2009 (Trier), 169-201.

Powell, J.G.F. 1988. (ed.) Cicero: Cato Maior de senectute (Cambridge).

Reggi, G. 2002. Cesare e il racconto delle battaglie navali sotto Marsiglia, RIL 136, 71-108. Rood, T.C.B. 2014. Space and Landscape in Xenophon's Anabasis, in: Gilhuly, K., Worman, N. (eds.), Space, Place, and Landscape in Ancient Greek Literature and Culture (New York and Cambridge), 63-93.

Rood, T.C.B. forthcoming. Geographical and Historical Patterning in Diodorus Siculus, in: Meuss, A. (ed.), Hellenistic Historiography (Histos Supplement). 
Rubincam C. 2003. Numbers in Greek Poetry and Historiography: Quantifying Fehling, CQ $53,448-463$.

Russell, D.A. 2001. (ed.) Quintilian: The Orator's Education, 5 vols (Cambridge MA).

Russo, F. 2010. Le Termopili come 'luogo ideologico’ nella propaganda romana, SCO 56, $31-56$.

Samotta, I. 2012. Herodotus and Thucydides in Roman Republican Historiography, in:

Foster, E., Lateiner, D. (eds.), Thucydides and Herodotus (Oxford), 345-378.

Scapini, M. 2011. Temi greci e citazioni da Erodoto nelle storie di Roma arcaica

(Nordhausen).

Sciarrino, E. 2004. Putting Cato the Censor's Origines in its Place, ClAnt 23, 323-357.

Thomas, R.F. 1986. Virgil's Georgics and the Art of Reference, HSCPh 90, 171-198.

Tränkle, H. 1971. Cato in der vierten und fünften Dekade des Livius (Mainz).

Welch, K. 1998. Caesar and his Officers in the Gallic War Commentaries, in Welch, K., Powell, A. (eds.), Julius Caesar as Artful Reporter: The War Commentaries as Political Instruments (London and Swansea), 85-110.

Woodman, A.J. 2014. (ed.) Tacitus: Agricola (Cambridge).

Zorzetti, N. 1990. The Carmina Convivalia, in: Murray, O. (ed.), Sympotica: A Symposium on the Symposion (Oxford), 289-307. 